\title{
QU"
}

\section{PRODUÇÃO DE DOCE DE BETERRABA EXÓTICO}

MELO, L. R. S. (IFRN), OLVEIRA, J. B. (IFRN), MENEZES, M. L. S. (IFRN)

Palavras Chave: Produção, doce, beterraba.

\section{INTRODUÇÃO}

Sabores doces são os favoritos de grande parte da humanidade. Tanto que a palavra "doce" virou sinônimo de tudo o que é agradável

A Beterraba é um vegetal de cor vermelha, que é doce e possuir vários benefícios para saúde. Além disso, A Beterraba podem ser comida cru, grelhado, cozido ou assado. $A$ beterraba é rica em vitaminas $A, B$ e $C$, e sais como o potássio, fosforo, cálcio, zinco, ferro e manganês, além de ser um vegetal de baixo teor calórico.

A beta vulgaris L., nome científico da beterraba pertencente à família Chenopodiaceae, que é uma hortaliça tuberosa da qual a raiz é comestível (CUCHINSKI, CAETANO \& DRAGUNSKI, 2010). O objetivo do trabalho é produzir um doce da beterraba, assim mostra uma alternative para as pessoas que não gosta desse legume, ingeri-lo.

\section{METODOLOGIA}

Cortou-se a beterraba em rodelas, e em seguida colocamos em uma panela intercalando com açúcar, e colou-se no fogo baixo, em 10 minutos a beterraba virou um caramelo, adicionou-se um copo de agua e levou-se ao liquidificador e bateu. Depois do liquidificador coou-se a mistura em um pano. Adiciou-se a aguardente e o leite condensado, bateu novamente no liquidificador, e em seguida levou-se ao fogo para encorpar.

\section{RESULTADOS E DISCUSSÕES}

A partir do doce de beterraba produzido, levamos o doce a quinze pessoas para degustar, onde eles responderam a seguinte pergunta: gostaram do doce? Eles tinham que responder sim ou não, e se não dizer porquê.
Figura 1 - Doce produzido.

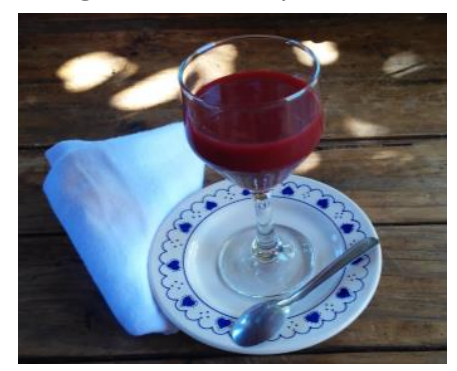

Figura 2 - Resultados em porcentagem das respostas dos degustadores.

RESPOSTA DOS DEGUSTADORES

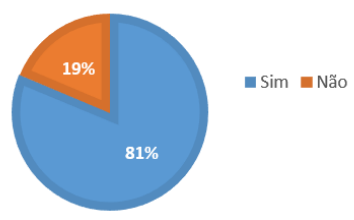

\section{CONCLUSÃO}

Conclui-se que o doce da beterraba é bem saboroso, e foi bem aceito pelas pessoas, e até mesmo para quem não gosta desse legume, em estudos posteriores pode ser feito análises da qualidade desse doce.

\section{REFERÊNCIAS}

1.Disponível em:

$<$ http://super.abril.com.br/ciencia/aimportancia-dos-doces $>$. Acessado em 14 de agosto de 2016

2. CUCHINSKI, A. S.; CAETANO, J.; DRAGUNSKI, D. C. Extração do Corante da Beterraba

(Beta Vulgaris) para Utilização como Indicador Ácido-Base. Eclética Química, v. 35, n. 4, p. 17 $-23,2010$. 